\title{
Sphaerisporangium krabiense sp. nov., isolated from soil
}

Correspondence

Vichien Kitpreechavanich fsciwck@ku.ac.th

\author{
Chanwit Suriyachadkun, ${ }^{1,2}$ Suwanee Chunhametha, ${ }^{2}$ \\ Wipaporn Ngaemthao, ${ }^{2}$ Tomohiko Tamura, ${ }^{3}$ Kanyawim Kirtikara, $^{2}$ \\ Jean-Jacques Sanglier ${ }^{2,4}$ and Vichien Kitpreechavanich ${ }^{1}$ \\ ${ }^{1}$ Faculty of Science, Kasetsart University, Bangkok 10900, Thailand \\ ${ }^{2}$ Bioresources Technology Unit, National Center for Genetic Engineering and Biotechnology, \\ National Science and Technology Development Agency, 113 Thailand Science Park, \\ Phaholyothin Road, Klong 1, Klong Luang, Pathumthani 12120, Thailand \\ ${ }^{3}$ Biological Resource Center, National Institute of Technology and Evaluation, \\ 2-5-8 Kazusakamatari, Kisarazu, Chiba 292-0812, Japan \\ ${ }^{4}$ Novartis Institutes for BioMedical Research Basel, Natural Products Unit, Novartis Pharma AG, \\ Basel, Switzerland
}

\begin{abstract}
A Gram-staining-positive, filamentous bacterial strain, designated A-T $0308^{\top}$, was isolated from soil of a tropical mangrove forest in Thailand. Strain A-T $0308^{\top}$ developed spherical sporangia containing non-motile spores on aerial mycelium. The novel strain contained meso-diaminopimelic acid, $N$-acetyl-type peptidoglycan and madurose, mannose, ribose, galactose and glucose as whole-cell sugars. The predominant menaquinones were $\mathrm{MK}-9\left(\mathrm{H}_{4}\right)$ and $\mathrm{MK}-9\left(\mathrm{H}_{6}\right)$; a small amount of MK-9(- $\left.\mathrm{H}_{2}\right)$ and MK-9 was also detected. Mycolic acids were not detected. The diagnostic phospholipids were phosphatidylethanolamine, diphosphatidylglycerol, phosphatidylinositol, phosphatidylinositol mannoside and phosphoglycolipid. The predominant cellular fatty acids were iso- $C_{16: 0}$ and 10-methylated $C_{17: 0}$. The $G+C$ content of the DNA was $72 \mathrm{~mol} \%$. Phenotypic and chemotaxonomic analyses showed that the novel isolate had characteristics typical of members of the genus Sphaerisporangium. 16S rRNA gene sequence analysis also indicated that the strain belongs to the genus Sphaerisporangium and that it represents a clade distinct from other members of the genus with sequence similarities ranging from 96.3 to $97.8 \%$ between the novel strain and its closest relatives. Based on the results of phenotypic, chemotaxonomic and phylogenetic studies, strain A-T 0308 ${ }^{\top}$ (=BCC $21702^{\top}$ $=$ NBRC $107571^{\top}$ ) represents a novel species of the genus Sphaerisporangium, for which the name Sphaerisporangium krabiense sp. nov. is proposed.
\end{abstract}

The genus Sphaerisporangium was first proposed by Ara \& Kudo (2007) as a member of the family Streptosporangiaceae. At the time of writing, the genus included six species with validly published names: Sphaerisporangium melleum (the type species of the genus), Sphaerisporangium rubeum, Sphaerisporangium cinnabarinum and Sphaerisporangium viridialbum (Ara \& Kudo, 2007) and Sphaerisporangium flaviroseum and Sphaerisporangium album (Cao et al., 2009).

Abbreviations: meso- $\mathrm{A}_{2} \mathrm{pm}$, meso-diaminopimelic acid; $\mathrm{ML}$, maximumlikelihood; MP, maximum-parsimony; $\mathrm{NJ}$, neighbour-joining.

The GenBank/EMBL/DDBJ accession number for the 16S rRNA gene sequence of strain A-T $0308^{\top}$ is $\mathrm{HM}^{\mathrm{N}} 037365$.

Two supplementary figures and two supplementary tables are available with the online version of this paper.
During the course of a project investigating the diversity of actinomycetes in Thailand, a Gram reaction-positive, nonacid-fast, aerobic bacterial strain, designated A-T $0308^{\mathrm{T}}$, was isolated from forest soil in Krabi Province. The novel isolate was identified as a member of the genus Sphaerisporangium based on the results of morphological, chemotaxonomic and phylogenetic analyses as well as DNA-DNA relatedness studies. Here, we report the taxonomic characterization and classification of strain A-T $0308^{\mathrm{T}}$ and propose that it represents a novel species.

Strain A-T $0308^{\mathrm{T}}$ was isolated from tropical mangrove forest soil collected in Krabi Province ( $8^{\circ} 3^{\prime} \mathrm{N} 98^{\circ} 47^{\prime} \mathrm{E}$ ), Thailand, and was kept at $4{ }^{\circ} \mathrm{C}$ prior to isolation. The soil sample was dried at room temperature for 8 days and the method of Nonomura \& Hayakawa (1988) was used for isolation. The organism was isolated on humic acid-vitamin agar (HV) 
supplemented with $25 \mathrm{mg}$ nalidixic acid $\mathrm{l}^{-1}, 50 \mathrm{mg}$ cycloheximide $\mathrm{l}^{-1}$ and $1 \mathrm{mg}$ terbinafine $\mathrm{l}^{-1}$. The pure culture was preserved by freezing at $-80{ }^{\circ} \mathrm{C}$ in $10 \%(\mathrm{v} / \mathrm{v})$ glycerol and also by liquid-drying.

Morphological characteristics were determined by growth on modified soil-extract agar, yeast extract-starch agar (Suriyachadkun et al., 2009) and inorganic salts-starch agar (ISP4 medium; Shirling \& Gottlieb, 1966) for 714 days at $28{ }^{\circ} \mathrm{C}$ followed by observation with a light microscope and a scanning electron microscope (model JSM-5410 LV; JEOL). Samples on modified soil-extract agar were prepared for scanning electron microscopy as described previously (Itoh et al., 1989).

Strain A-T $0308^{\mathrm{T}}$ had characteristics typical of members of the genus Sphaerisporangium. Cells developed spherical sporangia on aerial mycelium. Globose bodies were not observed. Spores were not motile as determined with a light microscope using cells grown on modified soil-extract agar for 3 weeks at $28{ }^{\circ} \mathrm{C}$ and then incubated at $28{ }^{\circ} \mathrm{C}$ for 30 $60 \mathrm{~min}$ in $0.1 \mathrm{M}$ potassium phosphate buffer $(\mathrm{pH} 7)$.

Phenotypic characteristics of the novel strain were examined using several standard methods. Cultural characteristics were tested using cells grown at $28{ }^{\circ} \mathrm{C}$ on various agar media for 14-21 days (Shirling \& Gottlieb, 1966). The NBS-ISCC Colour System was used to determine names and designations of colony colours. Growth at different temperatures, $\mathrm{pH}$ levels and $\mathrm{NaCl}$ concentrations was determined on ISP2 medium. Utilization of carbohydrates as sole carbon sources was tested by using ISP-9 medium as a basal medium (Shirling \& Gottlieb, 1966) supplemented with $1 \%$ (final concentration) of each of the carbon sources. Hydrolysis of high molecular mass compounds was determined using the media and method of Gordon et al. (1974). Gelatin liquefaction, peptonization of milk, nitrate reduction and starch hydrolysis were determined through cultivation on various media as described by Arai (1975) and Williams \& Cross (1971). Catalase and oxidase activities were determined using the method of Greenwood \& Pickett (1979). The results of these tests are given in the species description and Table 1.

Freeze-dried cells obtained from a culture grown in glucoseyeast extract broth (Tamura et al., 1994) on a rotary shaker at $30{ }^{\circ} \mathrm{C}$ for 7 days were used for chemotaxonomic analyses. The cell-wall peptidoglycan was prepared and hydrolysed by using the methods of Kawamoto et al. (1981), and the amino acid composition was analysed by TLC (Lechevalier \& Lechevalier, 1980). An isomer of diaminopimelic acid $\left(\mathrm{A}_{2} \mathrm{pm}\right)$ was detected in the cell wall by using the method of Staneck \& Roberts (1974). An acyl group of muramic acid was detected in the peptidoglycan by using the method of Uchida \& Aida (1984). Sugars were analysed from whole-cell hydrolysates using cellulose TLC, following the method of Komagata \& Suzuki (1987). Phospholipids were extracted and analysed by using the method of Minnikin et al. (1984). Fatty acid methyl ester analysis was performed by GLC according to the instructions of the ACTINO database of the
Microbial Identification System (MIDI) (Sasser, 1990; Kämpfer \& Kroppenstedt, 1996). Isoprenoid quinones were extracted according to the method of Collins et al. (1977) and analysed by HPLC using Cosmosil $5 \mathrm{C}_{18}$ columns $(4.6 \times 150 \mathrm{~mm}$; Nacalai Tesque $)$ with a mixture of methanol and 2-propanol $(2: 1, \mathrm{v} / \mathrm{v})$ as the elution solvent.

Chemotaxonomic characteristics of the novel strain were similar to those of the members of the genus Sphaerisporangium. The cell-wall amino acids contained mesodiaminopimelic acid (meso- $\left.\mathrm{A}_{2} \mathrm{pm}\right)$. The novel strain contained madurose, mannose, ribose, galactose and glucose as whole-cell sugars but not rhamnose, arabinose or xylose (whole-cell sugar pattern B of Lechevalier \& Lechevalier, 1970). Diphosphatidylglycerol, phosphatidylethanolamine, phosphatidylinositol, phosphatidylinositol mannoside and phosphoglycolipid were detected but phosphatidylcholine and glucosamine-containing phospholipids were not detected (Supplementary Fig. S1, available in IJSEM Online). This pattern corresponds to phospholipid type PIV of Lechevalier et al. (1977). The major cellular fatty acids of strain A-T $0308^{\mathrm{T}}$ were iso- $\mathrm{C}_{16: 0}(69.28 \%)$ and 10 methylated $\mathrm{C}_{17: 0}(9.19 \%)$, corresponding to fatty acid pattern 3c of Kroppenstedt (1985). Detailed cellular fatty acid compositions of strain A-T $0308^{\mathrm{T}}$ and type strains of the six recognized species of the genus Sphaerisporangium are shown in Supplementary Table S1. Mycolic acids were absent from strain A-T $0308^{\mathrm{T}}$. Menaquinones found in the novel isolate were MK- $9\left(\mathrm{H}_{4}\right)(66.47 \%)$, MK- $9\left(\mathrm{H}_{6}\right)$ $(20.86 \%)$, MK-9 $\left(\mathrm{H}_{2}\right)(9.62 \%)$ and MK-9 $\left(\mathrm{H}_{0}\right)(3.05 \%)$.

Genomic DNA was prepared according to the method of Saito \& Miura (1963). The 16S rRNA gene was amplified by PCR as described previously (Yamada et al., 2000; Katsura et al., 2001; Kawasaki et al., 1993). Two primers, 20F and 1500R (Suriyachadkun et al., 2009), were used for preliminary phylogenetic analysis. Positions in the rRNA gene fragments were based on the Escherichia coli numbering system (accession number V00348; Brosius et al., 1981). The amplified 16S rRNA gene was sequenced directly with an ABI PRISM BigDye Terminator cycle sequencing ready reaction kit using an ABI PRISM model 310 Genetic Analyzer (Applied Biosystems). The following primers were used for sequencing: 20F, 520F, 920F, 520R, 920R and 1500R (Yukphan et al., 2004). Multiple alignments of the sequences were carried out with the software BioEdit Sequence Alignment Editor (version 7.0.0). Distance matrices for the aligned sequences were calculated by using the two-parameter method of Kimura (1980). Phylogenetic trees were reconstructed from 1302 bases by using the neighbour-joining (NJ; Saitou \& Nei, 1987) and maximum-parsimony (MP; Felsenstein, 1983) methods in MEGA v4.0 and the maximum-likelihood (ML) method in PHYLIP v3.6 (Felsenstein, 1981). The robustness of individual branches was estimated by bootstrapping with 1000 replications (Felsenstein, 1985). Pair-wise sequence similarities were calculated for $16 \mathrm{~s}$ rRNA gene sequences $(1341 \mathrm{nt})$. Strain A-T $0308^{\mathrm{T}}$ exhibited $16 \mathrm{~S}$ rRNA gene sequence similarities of 97.8, 97.3, 97.3, 97.3, 96.9 and $96.3 \%$ to S. melleum $3-28(8)^{\mathrm{T}}$, S. album YIM $48782^{\mathrm{T}}$, S. 
Table 1. Characteristics differentiating strain $\mathrm{A}-\mathrm{T} 0308^{\top}$ and the six recognized species of the genus Sphaerisporangium

Strains: 1 , S. krabiense A-T $0308^{\mathrm{T}}$; 2, S. melleum $3-28(8)^{\mathrm{T}}$; 3, S. rubeum 3D-72(35) ${ }^{\mathrm{T}}$; 4, S. cinnabarinum DSM $44094^{\mathrm{T}}$; 5, S. viridialbum DSM 43801 ${ }^{\mathrm{T}}$; 6, S. flaviroseum YIM $48771^{\mathrm{T}}$; 7, S. album YIM $48782^{\mathrm{T}}$. +, Positive; -, negative; w, weakly positive. All data are from this study unless otherwise indicated.

\begin{tabular}{|c|c|c|c|c|c|c|c|}
\hline Characteristics & 1 & 2 & 3 & 4 & 5 & 6 & 7 \\
\hline \multicolumn{8}{|l|}{ Colonies on ISP 2 medium } \\
\hline Aerial mycelium or spore & Greyish pink & - & - & - & - & - & Pinkish white \\
\hline Substrate mycelium & Vivid red & Honey gold & Coral red & Bamboo & Light tan & $\begin{array}{l}\text { Deep yellow } \\
\text { pink }\end{array}$ & Pale grey \\
\hline Growth at $37{ }^{\circ} \mathrm{C}$ & + & + & + & + & - & - & + \\
\hline DNA G $+\mathrm{C}$ content $(\mathrm{mol} \%)^{\star}$ & 72 & 71 & 70.4 & 70 & 72 & 67.1 & 71 \\
\hline Major menaquinones ${ }^{*}$ & $\begin{array}{r}\text { MK-9 }\left(\mathrm{H}_{4}\right) \\
\text { MK-9 }\left(\mathrm{H}_{6}\right)\end{array}$ & $\begin{array}{r}\text { MK-9 }\left(\mathrm{H}_{4}\right) \\
\text { MK-9 }\left(\mathrm{H}_{6}\right)\end{array}$ & $\begin{array}{r}\text { MK-9 }\left(\mathrm{H}_{6}\right) \\
\text { MK-9 }\left(\mathrm{H}_{4}\right)\end{array}$ & $\begin{array}{r}\text { MK-9 }\left(\mathrm{H}_{4}\right) \\
\text { MK-9( }\left(\mathrm{H}_{6}\right)\end{array}$ & $\begin{array}{r}\text { MK-9 }\left(\mathrm{H}_{4}\right) \\
\text { MK-9 }\left(\mathrm{H}_{2}\right)\end{array}$ & $\begin{array}{c}\mathrm{MK}-9\left(\mathrm{H}_{4}\right), \mathrm{MK}- \\
9\left(\mathrm{H}_{2}\right), \mathrm{MK}-9\end{array}$ & $\begin{array}{c}\text { MK-9 }\left(\mathrm{H}_{4}\right) \\
\text { MK-9 }\left(\mathrm{H}_{2}\right), \\
\text { MK-9 }\end{array}$ \\
\hline $\begin{array}{l}\text { Milk coagulation and } \\
\text { peptonization }\end{array}$ & + & + & - & - & - & - & - \\
\hline Nitrate reduction & + & + & + & $\mathrm{w}$ & - & - & - \\
\hline Oxidase activity & + & - & - & - & - & - & + \\
\hline Hydrolysis of starch & - & + & + & + & + & - & + \\
\hline $\mathrm{NaCl}$ tolerance $(\%)$ & 3.5 & 1 & 1.5 & 2 & 1.5 & 1 & 2 \\
\hline \multicolumn{8}{|l|}{ Utilization of: } \\
\hline L-Arabinose & $\mathrm{w}$ & - & $\mathrm{w}$ & $\mathrm{w}$ & $\mathrm{w}$ & + & $\mathrm{w}$ \\
\hline D-Fructose & - & $\mathrm{w}$ & + & - & - & + & $\mathrm{w}$ \\
\hline D-Galactose & $\mathrm{w}$ & + & $\mathrm{w}$ & $\mathrm{W}$ & $\mathrm{w}$ & + & + \\
\hline D-Glucose & $\mathrm{W}$ & + & + & + & $\mathrm{w}$ & + & + \\
\hline Lactose & + & + & + & $\mathrm{W}$ & $\mathrm{W}$ & + & + \\
\hline D-Mannitol & $\mathrm{w}$ & w & + & + & + & $\mathrm{W}$ & + \\
\hline Melibiose & + & + & - & + & + & + & + \\
\hline Raffinose & $\mathrm{w}$ & $\mathrm{w}$ & $\mathrm{w}$ & $\mathrm{w}$ & $\mathrm{w}$ & - & + \\
\hline D-Ribose & - & $\mathrm{w}$ & - & + & $\mathrm{w}$ & + & + \\
\hline L-Rhamnose & + & + & - & + & $\mathrm{w}$ & + & + \\
\hline D-Xylose & $\mathrm{W}$ & + & + & + & $\mathrm{w}$ & + & + \\
\hline Salicin & $\mathrm{w}$ & $\mathrm{w}$ & w & $\mathrm{w}$ & $\mathrm{w}$ & - & $\mathrm{w}$ \\
\hline L-Proline & + & - & + & + & + & $\mathrm{w}$ & + \\
\hline L-Serine & $\mathrm{w}$ & - & + & + & $\mathrm{w}$ & $\mathrm{w}$ & + \\
\hline L-Tryptophan & - & - & - & $\mathrm{w}$ & $\mathrm{w}$ & - & - \\
\hline Xanthine & $\mathrm{w}$ & - & $\mathrm{W}$ & + & $\mathrm{w}$ & - & - \\
\hline L-Valine & + & - & - & + & + & + & + \\
\hline
\end{tabular}

${ }^{\star}$ Data for columns 2-7 were taken from Cao et al. (2009).

cinnabarinum DSM $44094^{\mathrm{T}}$, S. viridialbum DSM $43801^{\mathrm{T}}, S$. flaviroseum YIM $48771^{\mathrm{T}}$ and S. rubeum $3 \mathrm{D}-72(35)^{\mathrm{T}}$, respectively. The phylogenetic tree (Fig. 1) reconstructed using the NJ, MP and ML methods, showing the phylogenetic relationship between strain A-T $0308^{\mathrm{T}}$ and the members of the family Streptosporangiaceae, revealed that this strain should be classified as a member of the genus Sphaerisporangium and showed that it was clearly separated from its closest relatives. The neighbour-joining tree (Supplementary Fig. S2a), maximum-parsimony tree (Supplementary Fig. S2b), and maximum-likelihood tree (Supplementary Fig. S2c) showed a similar tree topology.

The $\mathrm{G}+\mathrm{C}$ content of the genomic DNA was determined by the method of Tamaoka \& Komagata (1984). After treatment with P1 nuclease and alkaline phosphatase,
HPLC was performed using a Shimadzu LC-6AD apparatus equipped with a Cosmosil $5 \mathrm{C}_{18}$-AR column $(4.6 \times 150 \mathrm{~mm}$; Nacalai Tesque). DNA-DNA hybridizations were carried out in microdilution wells using the photobiotin-labelling method as described by Ezaki et al. (1989). DNA-DNA relatedness (\%) was determined using the colorimetric method (Verlander, 1992). The DNA G + C content of strain A-T $0308^{\mathrm{T}}$ was $72 \mathrm{~mol} \%$. The strain exhibited DNA-DNA relatedness levels with the type strains $S$. melleum $3-28(8)^{\mathrm{T}}$, S. rubeum 3D-72(35) ${ }^{\mathrm{T}}$, S. cinnabarinum DSM $44094^{\mathrm{T}}, S$. viridialbum DSM $43801^{\mathrm{T}}$, S. flaviroseum YIM $48771^{\mathrm{T}}$ and $S$. album YIM $48782^{\mathrm{T}}$ that were significantly below $70 \%$ (Supplementary Table S2), the cut-off point recommended by Wayne et al. (1987) for the delineation of bacterial species. The results of $16 \mathrm{~S}$ rRNA gene sequence analysis and DNA-DNA relatedness studies were sufficient to categorize 


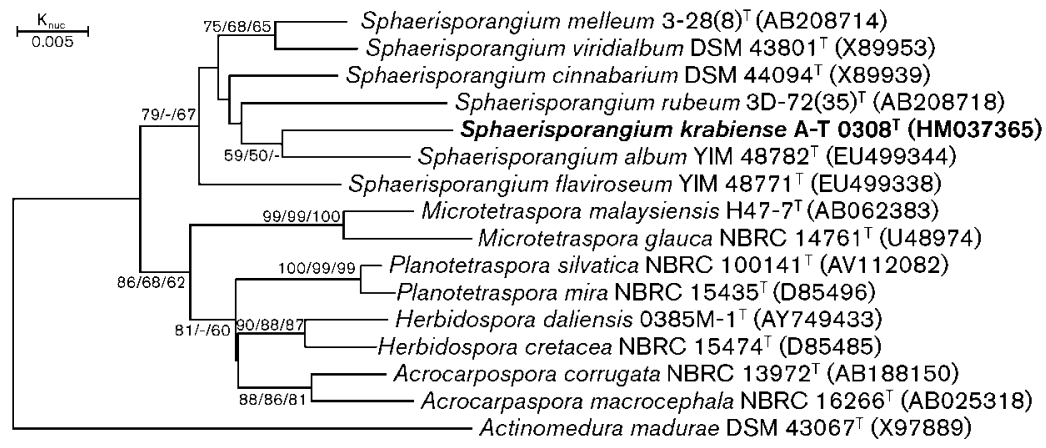

Fig. 1. Phylogenetic tree derived from $16 \mathrm{~S}$ rRNA gene sequences showing the relationship between strain A-T $0308^{\top}$ and closely related members of the family Streptosporangiaceae. The phylogenetic tree was reconstructed using the NJ, MP and ML methods. Actinomedura madurae DSM $43067^{\top}$ was used as an out group. Bootstrap values $>50 \%$, based on 1000 replications, are indicated at nodes (NJ/MP/ML). Bar, 0.005 substitutions per nucleotide position. strain A-T $0308^{\mathrm{T}}$ as distinct from previously described species of the genus Sphaerisporangium.

The phenotypic characteristics of strain A-T $0308^{\mathrm{T}}$ were compared with recognized species of the genus Sphaerisporangium (Table 1). The novel strain could grow in 3.5\% $(w / v) \mathrm{NaCl}$, whereas recognized species of the genus Sphaerisporangium could only grow in $<2 \%(\mathrm{w} / \mathrm{v}) \mathrm{NaCl}$. The novel strain also contained a larger amount $(>60 \%)$ of the fatty acid iso- $\mathrm{C}_{16: 0}$ than the other characterized species and did not contain iso- $\mathrm{C}_{15: 0}$, which was present in all the other strains used for comparison (Supplementary Table S1). These phenotypic and genotypic data indicated that strain A-T $0308^{\mathrm{T}}$ merits classification as a novel species of the genus Sphaerisporangium, for which the name Sphaerisporangium krabiense sp. nov. is proposed.

\section{Description of Sphaerisporangium krabiense sp. nov.}

Sphaerisporangium krabiense (kra.bi.en'se. N.L. neut. adj. krabiense of Krabi Province, Thailand, where the type strain was isolated).

Cells are Gram-reaction-positive, mesophilic, non-motile actinomycetes that form pink substrate mycelia and pinkgrey aerial mycelia on ISP2 medium. Spherical sporangia containing non-motile spores are formed on aerial mycelia. Substrate mycelium is non-fragmented. No soluble pigment is detected on ISP2, 3, 4 and 5 media. Optimal temperature for growth is between 25 and $37{ }^{\circ} \mathrm{C}$. Maximum $\mathrm{NaCl}$ concentration for growth is $3.5 \%$. Catalase- and oxidasepositive. Utilizes L-arabinose, cellobiose, D-galactose, Dglucose, lactose, D-mannitol, melibiose, raffinose, L-rhamnose, salicin and D-xylose as sole carbon and energy sources but does not utilize D-fructose, glycerol or D-ribose. Hydrolyses casein, hypoxanthine, L-ornithine, L-phenylalanine, L-proline, L-serine, L-tyrosine, $\mathrm{L}$-valine and xanthin but not adenine, L-glycine or L-tryptophan. Positive for nitrate reduction, milk coagulation and peptonization but negative for hydrolysis of starch and gelatin liquefaction. Contains meso- $\mathrm{A}_{2} \mathrm{pm}$ as the cell-wall amino acid and $\mathrm{N}$-acetyl-type peptidoglycan. Mycolic acids are not detected. The predominant menaquinones are MK-9 $\left(\mathrm{H}_{4}\right)$ and MK- $9\left(\mathrm{H}_{6}\right)$; small amounts of MK-9 $\left(\mathrm{H}_{2}\right)$ and MK-9 are also detected. The whole-cell sugars are madurose, mannose, ribose, galactose and glucose. The diagnostic phospholipids are phosphatidylethanolamine, diphosphatidylglycerol, phosphatidylinositol, phosphatidylinositol mannoside and phosphoglycolipid, corresponding to phospholipid pattern type PIV. The major fatty acids are iso- $\mathrm{C}_{16: 0}$ and 10-methylated $\mathrm{C}_{17: 0}$.

The type strain, A-T $0308^{\mathrm{T}}\left(=\mathrm{BCC} 21702^{\mathrm{T}}=\mathrm{NBRC} 107571^{\mathrm{T}}\right)$, was isolated from soil of a tropical mangrove forest in Thailand. The DNA G+C content of the type strain is $72 \mathrm{~mol} \%$.

\section{Acknowledgements}

We are grateful to Novartis Pharma AG for supporting this project, in particular Esther Schmitt, Rowan Morris, Peter Jager and Frank Petersen. We thank the Biological Resource Center, National Institute of Technology and Evaluation (NITE-NBRC), Chiba, Japan for supplying cultures of reference strains. This study was supported by Bioresources Research Network (BRN), Bangkok, Thailand.

\section{References}

Ara, I. \& Kudo, T. (2007). Sphaerosporangium gen. nov., a new member of the family Streptosporangiaceae, with descriptions of three new species as Sphaerosporangium melleum sp. nov., Sphaerosporangium rubeum sp. nov. and Sphaerosporangium cinnabarinum sp. nov., and transfer of Streptosporangium viridialbum Nonomura and Ohara 1960 to Sphaerosporangium viridialbum comb. nov. Actinomycetologica 21, $11-21$.

Arai, T. (1975). Culture Media for Actinomycetes. Tokyo: The Society for Actinomycetes Japan.

Brosius, J., Dull, T. J., Sleeter, D. D. \& Noller, H. F. (1981). Gene organization and primary structure of a ribosomal RNA operon from Escherichia coli. J Mol Biol 148, 107-127.

Cao, Y. R., Jiang, Y., Xu, L. H. \& Jiang, C. L. (2009). Sphaerisporangium flaviroseum sp. nov. and Sphaerisporangium album sp. nov., isolated from forest soil in China. Int J Syst Evol Microbiol 59, 1679-1684.

Collins, M. D., Pirouz, T., Goodfellow, M. \& Minnikin, D. E. (1977). Distribution of menaquinones in actinomycetes and corynebacteria. J Gen Microbiol 100, 221-230.

Ezaki, T., Hashimoto, Y. \& Yabuuchi, E. (1989). Fluorometric deoxyribonucleic acid-deoxyribonucleic acid hybridization in microdilution wells as an alternative to membrane filter hybridization in which radioisotopes are used to determine genetic relatedness among bacterial strains. Int J Syst Bacteriol 39, 224-229. 
Felsenstein, J. (1981). Evolutionary trees from DNA sequences: a maximum likelihood approach. J Mol Evol 17, 368-376.

Felsenstein, J. (1983). Parsimony in systematics: biological and statistical issues. Annu Rev Ecol Syst 14, 313-333.

Felsenstein, J. (1985). Confidence limits on phylogenies: an approach using the bootstrap. Evolution 39, 783-791.

Gordon, R. E., Barnett, D. A., Handerhan, J. E. \& Pang, C. H.-N. (1974). Nocardia coeliaca, Nocardia autotrophica, and the nocardin strain. Int J Syst Bacteriol 24, 54-63.

Greenwood, J. R. \& Pickett, M. J. (1979). Salient features of Haemophilus vaginalis. J Clin Microbiol 9, 200-204.

Itoh, T., Kudo, T., Parenti, F. \& Seino, A. (1989). Amended description of the genus Kineosporia, based on chemotaxonomic and morphological studies. Int J Syst Bacteriol 39, 168-173.

Kämpfer, P. \& Kroppenstedt, R. M. (1996). Numerical analysis of fatty acid patterns of coryneform bacteria and related taxa. Can $J$ Microbiol 42, 989-1005.

Katsura, K., Kawasaki, H., Potacharoen, W., Saono, S., Seki, T., Yamada, Y., Uchimura, T. \& Komagata, K. (2001). Asaia siamensis sp. nov., an acetic acid bacterium in the $\alpha$-Proteobacteria. Int J Syst Evol Microbiol 51, 559-563.

Kawamoto, I., Oka, T. \& Nara, T. (1981). Cell wall composition of Micromonospora olivoasterospora, Micromonospora sagamiensis, and related organisms. J Bacteriol 146, 527-534.

Kawasaki, H., Hoshino, Y., Hirata, A. \& Yamasato, K. (1993). Is intracytoplasmic membrane structure a generic criterion? It does not coincide with phylogenetic interrelationships among phototrophic purple nonsulfur bacteria. Arch Microbiol 160, 358-362.

Kimura, M. (1980). A simple method for estimating evolutionary rates of base substitutions through comparative studies of nucleotide sequences. J Mol Evol 16, 111-120.

Komagata, K. \& Suzuki, K. I. (1987). Lipid and cell-wall analysis in bacterial systematics. Methods Microbiol 19, 161-207.

Kroppenstedt, R. M. (1985). Fatty acid and menaquinone analysis of actinomycetes and related organisms. In Chemical Methods in Bacterial Systematics, pp. 173-199. Edited by M. Goodfellow \& D. E. Minnikin. London: Academic Press.

Lechevalier, M. P. \& Lechevalier, H. A. (1970). Chemical composition as a criterion in the classification of aerobic actinomycetes. Int J Syst Bacteriol 20, 435-443.

Lechevalier, M. P. \& Lechevalier, H. A. (1980). The chemotaxonomy of actinomycetes. In Actinomycete Taxonomy, pp. 227-291. Edited by A. Dietz \& D. W. Thayer. Arlington, VA: Society for Industrial Microbiology.

Lechevalier, M. P., De Bievre, C. \& Lechevalier, H. (1977). Chemotaxonomy of aerobic actinomycetes: phospholipid composition. Biochem Syst Ecol 5, 249-260.

Minnikin, D. E., O’Donnell, A. G., Goodfellow, M., Alderson, G., Athalye, M., Schaal, A. \& Parlett, J. H. (1984). An integrated procedure for the extraction of bacterial isoprenoid quinones and polar lipids. J Microbiol Methods 2, 233-241.

Nonomura, H. \& Hayakawa, M. (1988). New Methods for the Selective Isolation of Soil Actinomycetes. Biology of Actinomycetes. Tokyo: Japan Scientific Societies Press.

Saito, H. \& Miura, K. I. (1963). Preparation of transforming deoxyribonucleic acid by phenol treatment. Biochim Biophys Acta 72, 619-629.

Saitou, N. \& Nei, M. (1987). The neighbor-joining method: a new method for reconstructing phylogenetic trees. Mol Biol Evol 4, 406425.

Sasser, M. (1990). Identification of Bacteria by Gas Chromatography of Cellular Fatty Acids, Technical Note 101. Newark, DE: MIDI, Inc.

Shirling, E. B. \& Gottlieb, D. (1966). Methods for characterization of Streptomyces species. Int J Syst Bacteriol 16, 313-340.

Staneck, J. L. \& Roberts, G. D. (1974). Simplified approach to identification of aerobic actinomycetes by thin-layer chromatography. Appl Microbiol 28, 226-231.

Suriyachadkun, C., Chunhametha, S., Thawai, C., Tamura, T., Potacharoen, W., Kirtikara, K. \& Sanglier, J. J. (2009). Planotetraspora thailandica sp. nov., isolated from soil in Thailand. Int J Syst Evol Microbiol 59, 992-997.

Tamaoka, J. \& Komagata, K. (1984). Determination of DNA base composition by reversed-phase high-performance liquid chromatography. FEMS Microbiol Lett 25, 125-128.

Tamura, T., Nakagaito, Y., Nishii, T., Hasegawa, T., Stackebrandt, E. \& Yokota, A. (1994). A new genus of the order Actinomycetales, Couchioplanes gen. nov., with descriptions of Couchioplanes caeruleus (Horan and Brodsky 1986) comb. nov. and Couchioplanes caeruleus subsp. azureus subsp. nov. Int J Syst Bacteriol 44, 193-203.

Uchida, K. \& Aida, K. (1984). An improved method for the glycolate test for simple identification of the acyl type of bacterial cell walls. J Gen Appl Microbiol 30, 131-134.

Verlander, C. P. (1992). Detection of horseradish peroxidase by colorimetry. In Nonisotopic DNA Probe Techniques, pp. 185-201. Edited by L. J. Kricka. New York: Academic Press.

Wayne, L. G., Brenner, D. J., Colwell, R. R., Grimont, P. A. D., Kandler, O., Krichevsky, M. I., Moore, L. H., Moore, W. E. C., Murray, R. G. E. \& other authors (1987). International Committee on Systematic Bacteriology. Report of the ad hoc committee on reconciliation of approaches to bacterial systematics. Int J Syst Bacteriol 37, 463-464.

Williams, S. T. \& Cross, T. (1971). Actinomycetes. Methods Microbiol 4, 295-334.

Yamada, Y., Katsura, K., Kawasaki, H., Widyastuti, Y., Saono, S., Seki, T., Uchimura, T. \& Komagata, K. (2000). Asaia bogorensis gen. nov., sp. nov., an unusual acetic acid bacterium in the $\alpha$ Proteobacteria. Int J Syst Evol Microbiol 50, 823-829.

Yukphan, P., Potacharoen, W., Tanasupawat, S., Tanticharoen, M. \& Yamada, Y. (2004). Asaia krungthepensis sp. nov., an acetic acid bacterium in the $\alpha$-Proteobacteria. Int J Syst Evol Microbiol 54, 313-316. 